\title{
Supplementary taxonomic description of Demidospermus pinirampi (Monogenoidea, Dactylogyridae), with a new host record and an expansion of its distribution range
}

\author{
Julio Cesar Cenci de AGUIAR ${ }^{1 *}$, Glauco Baptista Franco BUENO², Sonia Maria Cursino dos SANTOS 3 , \\ Edson Aparecido ADRIANO ${ }^{1,4}$ \\ Universidade Estadual de Campinas, Programa de Pós-Graduação em Biologia Animal. Prédio da PG-IB, Bloco 0, CP. 6109, Avenida Bertrand Russel, s/n, 13083-865, \\ Campinas, São Paulo, Brasil \\ 2 Universidade Federal do Tocantins, Programa de Pós-Graduação em Ecologia de Ecótonos. Rua 03, Quadra 17, Lote 11, s/n, Setor Jardim dos Ipês, 77500-000, Porto Nacional, \\ Tocantins, Brasil \\ 3 Universidade de Taubaté, Departamento de Biologia. Av. Tiradentes, 500, Bom Conselho, 12030-180, Taubaté, São Paulo, Brasil \\ ${ }^{4}$ Universidade Federal de São Paulo, Departamento de Ecologia e Biologia Evolutiva. Rua Prof. Artur Riedel, 275, Jd. Eldorado, 09972-270, Diadema, São Paulo, Brasil \\ * Corresponding author: julio_aguiar@msn.com
}

\section{ABSTRACT}

During a survey conducted in the Lajeado Reservoir of the Tocantins River, in the state of Tocantins, Brazil, dactylogyrids were recovered from the gills of Pimelodina flavipinnis. Initial morphological analysis showed these dactylogyrids shared aspects of character with species of Demidospermus, with affinity to Demidospermus pinirampi, despite exhibiting differences with the original description by Kritsky et al. (1987) regarding the vagina, the base of the male copulatory organ and the shape and length of the bars. The analysis of the holotypes of $D$. pinirampi and its most morphologically close species, Demidospermus luckyi, revealed that these dactylogyrids were indeed $D$. pinirampi. This study therefore reports a new host and locality of occurrence, and reviews some measurements of the original description, supplementing and enhancing the morphological diagnosis of D. pinirampi.

KEYWORDS: South America, Tocantins, morphology, parasite, Pimelodidae

\section{Descrição taxonômica complementar de Demidospermus pinirampi (Monogenoidea, Dactylogyridae), com registro de um novo hospedeiro e ampliação de sua área de distribuição}

\section{RESUMO}

Durante um levantamento realizado no Reservatório de Lajeado, no Rio Tocantins, no estado de Tocantins, Brasil, dactilogirídeos foram recuperados das brânquias de Pimelodina flavipinnis. A análise morfológica inicial mostrou que esses dactilogirídeos compartilham aspectos de caráter com espécies de Demidospermus, com afinidade com Demidospermus pinirampi, apesar de apresentarem diferenças em relação à descrição original fornecida por Kritsky et al. (1987) com respeito à vagina, à base do órgão copulatório masculino e à forma e comprimento das barras. A análise dos holótipos de $D$. pinirampi e de sua espécie morfologicamente mais próxima, Demidospermus luckyi, revelou que estes dactilogirídeos eram realmente $D$. pinirampi. Este estudo, portanto, relata um novo hospedeiro e localidade de ocorrência e revisa algumas medidas da descrição original, complementando a diagnose morfológica de D. pinirampi.

PALAVRAS-CHAVE: América do Sul, Tocantins, morfologia, parasita, Pimelodidae 
Demidospermus pinirampi (Kritsky, Thatcher and Boeger, 1987) was described parasitizing gills of the pimelodid Pinirampus pirinampu (Spix and Agassiz, 1829) from the Janauacá Lake, near Manaus, state of Amazonas, Brazil (Kritsky et al. 1987). This parasite was originally classified within Omothecium Kritsky, Thatcher and Boeger, 1987, which was later synonymized to Demidospermus Suriano, 1983 (Kritsky and Gutiérrez 1998), and which today harbors 29 valid species (Cohen et al. 2013; Franceschini et al. 2017).

In a survey conducted between July and November of 2011, 71 specimens of Pimelodina flavipinnis Steindachner, 1876, a pimelodid found in the Orinoco, Amazon and Araguaia/ Tocantins basins (Lundberg and Littmann 2003; Froese and Pauly 2016), were examined for the presence of monogenoids. The fish were caught in the mid-Tocantins River, in the state of Tocantins, Brazil. The helminths recovered were fixed in $4 \%$ formalin, posteriorly stained with Gomoris's trichrome and mounted in Canada balsam for visualization of the soft tissues, or in Gray and Wess medium for the study of the sclerotized structures (Kritsky et al. 1986). Observations were carried out through differential interference contrast (DIC) and phase contrast using an Axioplan 2 Zeiss microscope. Illustrations were made with an optical microscope Olympus CBA with a drawing tube attached. The measurements were taken according to Mizelle and Klucka (1953), except the male copulatory organ, which was thoroughly measured, using ImageJ software (Rasband 2015). Holotypes of D. pinirampi (INPA 059 - in the original description reported as INPA PA 282-1) and of D. luckyi (Kritsky, Thatcher and Boeger, 1987) (INPA 058 - in the original description reported as INPA PA 283-1), borrowed from the non-Insecta invertebrate collection of the Instituto Nacional de Pesquisas da Amazônia - INPA (National Institute of Amazonian Research), were examined. Quantitative population descriptors were carried out as proposed by Bush et al. (1997). The specimens studied were deposited in the Platyhelminthes collection of the Museu de Zoologia da Universidade Estadual de Campinas "Adão José Cardoso" (Adão José Cardoso Zoology Museum of the State University of Campinas), in the state of São Paulo, Brazil, and in the non-Insecta invertebrate collection of INPA.

Initial taxonomic analysis revealed that the dactylogyrids recovered from $P$. flavipinnis in the Tocantins River shared aspects of character with species of Demidospermus, with close affinity to $D$. pinirampi. Notwithstanding this finding, some important differences with the original description by Kritsky et al. (1987) were observed in the morphology of the base of the male copulatory organ (MCO), the vagina and the haptoral bars, as well as some morphometric differences in the dimensions of the ventral and dorsal bars and the testis (Table 1). However, when confronted with the holotypes of D. pinirampi (INPA 059) and with its morphologically closest species, D. luckyi (INPA 058), it was observed that these dactylogyrids indeed corresponded to D. pinirampi. Following this finding, a comparative analysis between the samples and the holotype of D. pinirampi (INPA 059) (Table 1) was carried out to supplement and enhance the diagnosis of D. pinirampi.

Table 1. Morphometric data, in micrometers $(\mu \mathrm{m})$, of Demidospermus pinirampi from this study (specimens recovered from Pimelodina flavipinnis from the Tocantins River, Brazil), and from the original description in Kritsky et al. (1987), presenting separately the measurements of the holotype deposited in the collection of the National Institute of Amazonian Research - INPA. N is the number of specimens measured in this study. Values are means followed by the range in parentheses. The original description was based on five specimens, without specifying how many of those were measured.

\begin{tabular}{|c|c|c|c|c|}
\hline & $\mathrm{N}$ & Present study & $\begin{array}{c}\text { Original } \\
\text { description }\end{array}$ & $\begin{array}{l}\text { Holotype } \\
\text { INPA-059 }\end{array}$ \\
\hline body length & 11 & $895(637.5-1320)$ & $\begin{array}{c}952(924- \\
1004)\end{array}$ & 970 \\
\hline $\begin{array}{l}\text { greatest } \\
\text { width }\end{array}$ & 13 & $136(97.5-247.5)$ & $155(129-189)$ & 127 \\
\hline $\begin{array}{l}\text { pharynx } \\
\text { diameter }\end{array}$ & 13 & $68(36-112.5)$ & $74(68-78)$ & 65 \\
\hline haptor long & 13 & $69.5(41-101)$ & $90(73-112)$ & 64 \\
\hline haptor wide & 13 & $134(94-191)$ & $154(122-185)$ & 133 \\
\hline $\begin{array}{l}\text { ventral } \\
\text { anchor long }\end{array}$ & 13 & $42(30-48.5)$ & $44(41-47)$ & 44 \\
\hline $\begin{array}{l}\text { ventral } \\
\text { anchor wide }\end{array}$ & 13 & $22(17-26.25)$ & $24(20-27)$ & 23 \\
\hline $\begin{array}{l}\text { dorsal } \\
\text { anchor long }\end{array}$ & 13 & $39(21-45)$ & $41(37-45)$ & 45 \\
\hline $\begin{array}{l}\text { dorsal } \\
\text { anchor wide }\end{array}$ & 12 & $21(13-28)$ & $26(22-30)$ & 20 \\
\hline $\begin{array}{l}\text { ventral bar } \\
\text { long }\end{array}$ & 13 & $104(90-122)$ & $44(41-47)$ & 107 \\
\hline $\begin{array}{l}\text { dorsal bar } \\
\text { long }\end{array}$ & 13 & 77 (47-99) & $36-37$ & 81 \\
\hline hook 1 & 12 & $14(9-17)$ & - & 16 \\
\hline hook 2 & 11 & $10(6-11)$ & - & 9 \\
\hline hook 3 & 13 & $17(12-20)$ & - & - \\
\hline hook 4 & 12 & $16(13-18)$ & - & - \\
\hline hook 5 & 12 & $18(13-20)$ & - & 18 \\
\hline hook 6 & 13 & $17(12-20)$ & - & 17 \\
\hline hook 7 & 11 & $18(14-20)$ & - & 18 \\
\hline $\begin{array}{l}\text { acessory } \\
\text { piece long }\end{array}$ & 10 & $37(23-49)$ & $36(30-44)$ & - \\
\hline MCO long & 13 & $121(67-156)$ & $155-156$ & - \\
\hline testis long & 12 & $128(53-204)$ & $191(143-240)$ & 130 \\
\hline testis wide & 12 & $39(25-50)$ & $54(41-67)$ & 40 \\
\hline $\begin{array}{l}\text { germarium } \\
\text { long }\end{array}$ & 10 & $65(42-95)$ & $68(53-82)$ & 82 \\
\hline $\begin{array}{l}\text { germarium } \\
\text { wide }\end{array}$ & 10 & $30(19-42)$ & $37(31-43)$ & 31 \\
\hline egg size & 2 & $44 \times 28$ & - & - \\
\hline
\end{tabular}




\section{Taxonomic summary}

Class: Monogenoidea Bychowsky, 1937.

Family: Dactylogyridae Bychowsky, 1933.

Genus: Demidospermus Suriano, 1983.

Species: Demidospermus pinirampi (Kritsky, Thatcher and Boeger, 1987) (Figure 1).

Type host: Pinirampus pirinampu (Spix and Agassiz, 1829) (Siluriformes, Pimelodidae) (Kritsky et al. 1987).

Additional host: Pimelodina flavipinnis Steindachner, 1876 (Siluriformes, Pimelodidae) (this study).

Site: Gills.

Type locality: Janauacá Lake, near Manaus, Amazonas, Brazil (3²3’27.98”S, 60¹8'34.39”W) (Kritsky et al. 1987).

Additional locality: Reservoir of Lajeado, middle Tocantins River, municipality of Porto Nacional, Tocantins, Brazil (10²3'26.1”S, 48²4'57.6”W) (this study).

Prevalence of infection: $29.6 \%$.

Mean abundance of infection: 0.72 .

Mean intensity of infection: 2.43 .

Specimens studied: Holotype of D. pinirampi INPA 059; holotype of $D$. luckyi INPA 058 and; vouchers ZUEC PLA 69, 71, in Gomori's trichrome; vouchers ZUEC PLA 70, 72 , in Gray and Wess medium; vouchers INPA 729-730, in Gomori's trichrome; vouchers INPA 728, 731-736 in Grey and Wess medium.

The vagina observed in the specimens of the present study is conspicuous, with a wrinkled atrium resembling a trumpet flower (Figures 1A, 1C). This characteristic was also observed in the holotype examined (INPA 059), although it was not clear in the drawing from the original description (Kritsky et al. 1987). Although the morphology of the vaginal atrium contributes little to the phylogenetic proposal for some dactylogyrids (Wu et al. 2007), its proper characterization is useful for the discrimination of species, especially for closely related taxa (Wu et al. 2007; Wu et al. 2008; Aguiar et al. 2011).

With respect to the MCO, two conspicuous sclerotized flaps were observed in the base of the organ in the specimens of the present study (Figure 1). The number of flaps was not specified in the original description, which states only that the base of the MCO (cirrus) had a proximal "flare" (Kritsky et al. 1987). Examination of the INPA-059 holotype confirmed the presence of conspicuous flaps.

In terms of the bars, there appears to be a misunderstanding in the original description (Kritsky et al. 1987). In one part of the text, the authors report that the ventral bar is $\mathrm{V}$-shaped and the dorsal bar is usually W-shaped, but frequently flattened, and this information coincides with the drawing provided. However, in another part of the manuscript, the authors state that the ventral bar is $44 \mu \mathrm{m}$ in length, being longer than the dorsal bar, which is $36-37 \mu \mathrm{m}$. Examining the drawings

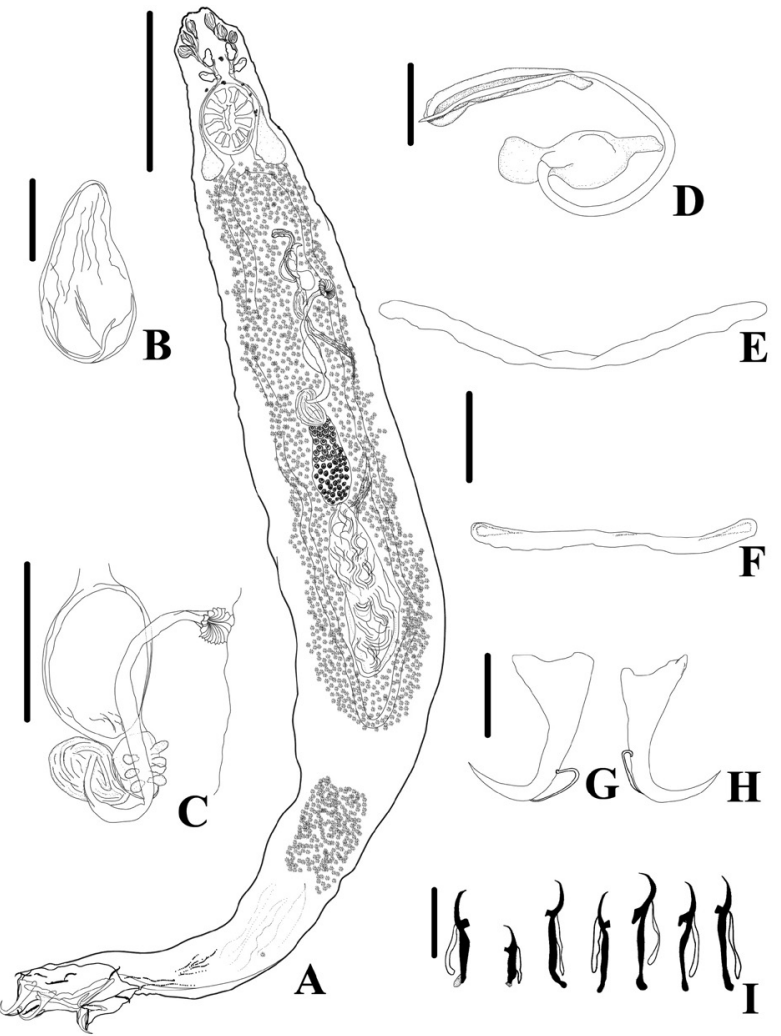

Figure 1. Demidospermus pinirampi, parasite of gills of Pimelodina flavipinnis from the Tocantins River, Brazil. A - composite drawing, ventral view; B - egg; C - female reprodutive system; D - male copulatory organ, dorsal view; E ventral bar; $\mathrm{F}$ - dorsal bar; $\mathrm{G}$ - ventral anchor; $\mathrm{H}$ - dorsal anchor; I - hook pairs 1 to 7 . Scale bars: $200 \mu \mathrm{m}$ (A), $40 \mu \mathrm{m}$ (Figs. E - F), $30 \mu \mathrm{m}$ (C), $25 \mu \mathrm{m}$ (B, D), $20 \mu \mathrm{m}(\mathrm{G}-\mathrm{H}), 10 \mu \mathrm{m}(\mathrm{l})$.

of bars in the original description, it can clearly be seen that the longer bar was that which the authors described as the dorsal bar, contradicting the latter information from Kritsky et al. (1987) about the length of the ventral and dorsal bars. In the present study the ventral bar was indeed longer and W or U-shaped, while the dorsal bar, shown as V-shaped in the INPA-059 holotype, was almost straight.

We also observed a major inconsistency regarding the bar dimensions in the original description (Kritsky et al. 1987). While those authors reported a length of $44 \mu \mathrm{m}$ for the ventral bar and 36-37 $\mu \mathrm{m}$ for the dorsal bar, measures of these structures in the present study were 104 and $77 \mu \mathrm{m}$, respectively, and 107 and $81 \mu \mathrm{m}$, respectively, for the INPA-059 holotype (Table 1). The scale of the drawing provided in the original description revealed that the dimensions of the bars were compatible with those obtained here, suggesting a misreading of the measurements presented by Kritsky et al. (1987).

The present study, as well as providing supplementary morphological data of $D$. pinirampi, which enables a more suitable diagnosis, reports the occurrence of this species in a 
different host and geographic region to the originally reported type host and locality, extending the distribution of the parasite to a different river basin. Despite the fact that 14 monogenoid species have so far been reported from the Tocantins Basin (Fehlauer and Boeger 2005; Boeger et al. 2006; Domingues and Marques 2007; Domingues et al. 2007; Domingues and Marques 2010; Kritsky et al. 2013), D. pinirampi is only the second dactylogryrid species registered in this watershed.

\section{ACKNOWLEDGEMENTS}

The authors would like to acknowledge Dr. Célio Magalhães, curator of the Non-Insecta Invertebrate Collection of Instituto Nacional de Pesquisas da Amazônia - INPA for kindly sending specimens for comparison in this study. We also acknowledge Dr. Elineide Eugênio Marques, from the Universidade Federal do Tocantis for providing support for the field work. Funding for the present study was provided by the Fundação de Amparo à Pesquisa do Estado de São Paulo - FAPESP (Proc. No. 2013/21374-6 - E.A. Adriano). J.C. Aguiar was funded by a postgraduate scholarship provided by the FAPESP 2013/207705. G.B.F. Bueno was funded by a postgraduate scholarship provided by Coordenação de Aperfeiçoamento de Pessoal de Nível Superior - CAPES. E.A. Adriano was supported by a research fellowship from Conselho Nacional de Desenvolvimento Científico e Tecnológico - CNPq (Proc. No.305630/2013-0).

\section{REFERENCES}

Aguiar, J.C.; Ceccarelli, P.S.; Luque, J.L. 2011. Two new species of Pavanelliella (Monogenea, Dactylogyridae) parasitic on pimedolid fishes from Mogi Guaçu river, Southeastern Brazil, and notes on the morphology of P.pavanellii. Neotropical Helminthology, 5: 213-224.

Boeger, W.A.; Fehlauer, K.H.; Marques, E.E. 2006. Neotropical Monogenoidea. 49. Four new species of the Diplectanidae (Dactylogyrinea) from the gills of some pachyurines (Teleostei: Sciaenidae) from the Rio Tocantins and Rio Doce Basins, with the proposal of Anoplectanum n. g. and Spinomatrix n. g. Systematic Parasitolology, 64: 57-68.

Bush, A.O.; Lafferty, K.D.; Lotz, J.M.; Shostak, A.W. 1997. Parasitology meets ecology on its own terms: Margolis et al. revisited. Journal of Parasitology, 83: 575-583.

Cohen, S.C.; Justo, M.C.N.; Kohn, A. 2013. South American Monogenoidea Parasites of Fishes, Amphibians and Reptiles. Oficina de Livros, Rio de Janeiro, 663p.

Domingues, M.V.; Marques, F.P.L. 2007. Revision of Potamotrygonocotyle Mayes, Brooks \& Thorson, 1981 (Platyhelminthes: Monogenoidea: Monocotylidae), with descriptions of four new species from the gills of the freshwater stingrays Potamotrygon spp. (Rajiformes: Potamotrygonidae) from the La Plata river basin. Systematic Parasitolology, 67: 157-174.

Domingues, M.V.; Marques, F.P.L. 2010. Phylogeny and taxonomy of Potamotrygonocotyle Mayes, Brooks \& Thorson, 1981 (Monogenoidea: Monocotylidae) with a description of four new species. Journal of Helminthology, 85: 353-380.
Domingues, M.V.; Pancera, N.C.M.; Marques, F.P.L. 2007. Monogenoidean parasites of freshwater stingrays (Rajiformes: Potamotrygonidae) from the Negro River, Amazon, Brazil: species of Potamotrygonocotyle (Monocotylidae) and Paraheteronchocotyle (Hexabothriidae). Folia Parasitologica, 54: 177.

Fehlauer, K.H.; Boeger, W.A. 2005. Neotropical Monogenoidea: Euryhaliotrema dontykoleos n. sp. (Dactylogyridae) from the gills of the freshwater sciaenid, Pachyurus junki (Perciformes). Journal of Parasitology, 91: 1025-1027.

Franceschini, L.; Zago, A.; Müller, M.; Francisco, C.; Takemoto, R.; da Silva, R. 2017. Morphology and molecular characterization of Demidospermus spirophallus n. sp., D. prolixus n. sp. (Monogenea: Dactylogyridae) and a redescription of $D$. anus in siluriform catfish from Brazil. Journal of Helminthology, 6: 1-16.

Froese, R.; Pauly, D. 2016. FishBase. World Wide Web electronic publication, (www.fishbase.org/search.php). Accessed on 10/2016.

Kritsky, D.; Thatcher, V.; Boeger, W. 1987. Neotropical Monogenea. 10: Omothecium, new genus (Dactylogyridae: Ancyrocephalinae) and two new species from the Piranambu, Pinirampus pirinampu (Spix),(Siluriformes), in Brazil. Proceedings of the Biological Society of Washington, 100: 8-12.

Kritsky, D.C.; Boeger, W.A.; Mendoza-Franco, E.F.; Vianna, R.T. 2013. Neotropical Monogenoidea. 57. Revision and phylogenetic position of Scleroductus Jara \& Cone, 1989 (Gyrodactylidae), with descriptions of new species from the Guatemalan chulin Rhamdia guatemalensis (Gunther) (Siluriformes: Heptapteridae) in Mexico and the barred sorubim Pseudoplatystoma fasciatum (Linnaeus) (Siluriformes: Pimelodidae) in Brazil. Systematic Parasitolology, 84: 1-15.

Kritsky, D.C.; Gutiérrez, P.A. 1998. Neotropical Monogenoidea. 34. Species of Demidospermus (Dactylogyridae, Ancyrocephalinae) from the gills of Pimelodids (Teleostei, Silurifores) in Argentina. Journal of the Helminthological Society of Washington, 65: 147-159.

Kritsky, D.C.; Thatcher, V.; Boeger, W. 1986. Neotropical Monogenea. 8. Revision of Urocleidoides (Dactylogyridae, Ancyrocephalinae). Proceedings of the Helminthological Society of Washington, 53: 1-37.

Lundberg, J.G.; Littmann, M.W. 2003. Family Pimelodidae (Longwiskered catfish). In: Reis, R. E.; Kullander, S. O.; Ferraris Jr, C. J. (Ed.). Check List of the Freshwater Fishes of South and Central America. Edipucrs, Porto Alegre, 729p.

Mizelle, J.D.; Klucka, A.R. 1953. Studies on monogenetic trematodes. XIV. Dactylogyridae from Wisconsin fishes. American Midland Naturalist, 49: 720-733.

Rasband, W.S. 2015. ImageJ, U. S. National Institutes of Health, (http://imagej.nih.gov/ij/). Accessed on 10/2016.

Wu, X.Y.; Zhu, X.Q.; Xie, M.Q.; Li, A.X. 2007. The evaluation for generic-level monophyly of Ancyrocephalinae (Monogenea, Dactylogyridae) using ribosomal DNA sequence data. Molecular Phylogenetics and Evolution, 44: 530-544.

Wu, X.Y.; Zhu, X.Q.; Xie, M.Q.; Wang, J.Q.; Li, A.X. 2008. The radiation of Thaparocleidus (Monogenoidea: Dactylogyridae: Ancylodiscoidinae): phylogenetic analyses and taxonomic implications inferred from ribosomal DNA sequences. Parasitology Research, 102: 283-288.

Received: 27/02/2017

Accepted: 05/07/2017 